\title{
Introduction
}

\section{The Necessity of a New Understanding of Responsibility for Modern Society}

Henkel, Anna; Åkerstrøm Andersen, Niels

\author{
Document Version \\ Final published version
}

Published in:

Soziale Systeme

DOI:

10.1515/sosys-2014-0203

Publication date:

2015

\section{License \\ CC BY-NC-ND}

Citation for published version (APA):

Henkel, A., \& Akerstrøm Andersen, N. (2015). Introduction: The Necessity of a New Understanding of

Responsibility for Modern Society. Soziale Systeme, 19(2), 221-232. https://doi.org/10.1515/sosys-2014-0203

Link to publication in CBS Research Portal

\section{General rights}

Copyright and moral rights for the publications made accessible in the public portal are retained by the authors and/or other copyright owners and it is a condition of accessing publications that users recognise and abide by the legal requirements associated with these rights.

Take down policy

If you believe that this document breaches copyright please contact us (research.lib@cbs.dk) providing details, and we will remove access to the work immediately and investigate your claim. 


\title{
Introduction: The Necessity of a New Understanding of Responsibility for Modern Society
}

\section{Niels Akerstrom Andersen and Anna Henkel}

\author{
Journal article (Publishers version)
}

Cite: Introduction : The Necessity of a New Understanding of Responsibility for Modern Society: / Henkel, Anna; Akerstrom Andersen, Niels. In: Soziale Systeme, Vol. 19, No. 2, 2015, p. 221-232.

DOI: http://dx.doi.org/10.1515/sosys-2014-0२०3

Uploaded to Research@CBS: August 2016

(1) 2016. This manuscript version is made available under the CC-BY-NC-ND 4.0 license http://creativecommons.org/licenses/by-nc-nd/4.0/ 


\section{Introduction: The necessity of a new understanding of responsibility for modern society}

The aim of this publication is to promote the interdisciplinary discussion of conditions, mechanisms and challenges of the attribution of responsibility under the condition of trust in systems, instead of trust in individual people. Traditionally, the concept of responsibility is understood in an individualized and frequently moral sense. In contrast to that, our starting hypothesis is that modern society is characterized by (potentially) critical constellations, in which the attribution of responsibility to individual people or organizations is not undisputedly possible. This holds for phenomena from the realm of technology, but is also true regarding social developments such as the latest financial crisis. This publication brings the perspectives of Political- and Management-Studies together with the perspective of Science- and TechnologyStudies as well as sociological, judicial and pedagogic viewpoints to scrutinize precarious attribution of responsibility as a phenomenon of the modern, functionally differentiated society: What new mechanisms and ways of attribution of responsibility evolve when a default in knowledge, systems or things cannot unequivocally be attributed to the mistake of an individual person? What significance do people have, if they are no longer the undisputed addresses of responsibility? And how does politics deal with the challenge to be of being held increasingly responsible for failed expectations?

1 For a theory-of-society point of view in the responsibility discussion

Responsibility is a genuinely modern concept. Neither Aristotle nor Plato mention the term or the idea of »responsibility«. When in the $15^{\text {th }}$ century the term first arises, it is essentially used in a judicial sense - responsibility means to "answer" a certain accusation. Duty and guilt are the dominant concepts for both the antique and the Christian world, not responsibility. Only in the $19^{\text {th }}$ century does responsibility gain a broader distribution; its status of a core category is a development of the late $20^{\text {th }}$ century (Bayertz 1995).

The general idea of this new term of responsibility is that certain results are attributed to individual actions. The concept of responsibility is thus strongly individualistic: it requires the idea that there are individuals who have cer- 
tain intentions and who are able to foresee the consequences of their actions and can thus be expected to take on the responsibility not only for their own health, education and lifestyle, but also for sustainable production methods, reasonable financial investment-instruments, and a stable civil society.

Accordingly, the concept of responsibility is essentially a moral term; its origin is closely connected with the apparent ecological crises in the 1970s and 1980s as well as the fear of an atomic catastrophe. Of particular influence in the responsibility discourse were Hans Jonas and Karl-Otto Apel. Hans Jonas argues that everybody has a direct personal responsibility to sustain the environment. The idea of the »future generations «, which is quite dominant in the later sustainability-discourse, is a key point in Jonas's argumentation (Jonas 1984). Karl-Otto Apel develops a discourse-ethical standpoint. He argues that today's conflicts require an ethical-political orientation; discourse-ethics must be understood as responsibility-ethics (Apel 1988). The concept responsibility< is thus looked upon and further developed from a moral point of view, which is connected with political recommendations. In addition, philosophy and politics are the dominant areas in which and for which the concept of responsibility is further developed.

In the late 1990s, the responsibility-discourse shifts more to the political area. A reason for this development might be that instead of the - still relevant ecological crisis, a welfare-state crisis becomes the dreadful scenario. Due to global economic competition and an increasingly obvious demographic change, welfare-state provision for individual risks such as unemployment, sickness and age seem to be at stake. In this situation, self-responsibility in a civil society is discussed as a »third way" between the state and the market. The self-responsibility of the citizen is to be »activated « in a situation, in which the state can no longer provide for all individual mischiefs in an undifferentiated way (Giddens 1999; Heidbrink 2006). The Schröder-Blair Agenda is a practical political result from this consideration.

But after ten years of »activation « the critical voices become louder. Ultimately, of course everybody is responsible for his or her own life - but can he or she be held responsible for unemployment, illness, the production of unsustainable food and the financial crisis? Are there not quite different starting positions of the »responsible citizen«, as far as both education and an inherited wealth are concerned (Kaufmann 2006; Nullmeier 2006; Schmidt 2008)?

The purpose of this special issue is to take this state of the responsibilitydiscourse as a reason to look at it from a new angle. Until now, responsibility is discussed either in a moral-philosophical or a political sense. We propose to add a society-theoretical point of view. The main characteristic of a societytheoretical viewpoint is that it observes the change of social structures and asks why such a change takes place (or does not take place). This starting point facilitates a more abstract and therefore more neutral position. It is no longer necessary to define what responsibility should be - but it is possible to 
observe, how this term is applied and which societal conditions correspond to this application. The semantics of responsibility and social structures of the attribution (and self-attribution) of responsibility can thus be related to each other, which enables changes in this structural arrangement to be observed. For this endeavor we take the end of the responsibility-discourse as our starting point: to attribute ecological or social crises to individual actions is obviously a precarious endeavor. In the light of this, we assume that modern society is mainly characterized by trust in systems instead of trust in individual people. If this is the case, what are the consequences for the attribution of responsibility (section 2)? Similar developments have been observed from different disciplinary viewpoints. These are first presented (section 3) before we formulate interdisciplinary questions that look at society as a whole (section 4). This special issue offers an interdisciplinary contribution, framed in a society-theoretical context, to the responsibility-discourse. With these new angles and insights, it hopes to give room to both better understand the unintended effects of an institutionalized self-responsibility, and to offer alternatives for political action in a world of risk and rising complexity.

\section{Precarious attribution of responsibility as the starting point}

Problematized since the 1970s is the fact that personal responsibility for technical but also social developments cannot easily be attributed to one distinct causing person. Technical products and processes are characterized by their at least marginal incalculability: Even extensive clinical tests cannot prevent severe unknown side-effects of drugs; extensive experiments in the laboratory cannot prevent the unforeseen and unforeseeable effects that innovations in real use may show (Krohn/Weyer 1989). Furthermore can social crises such as cost-expansion in the public sector, changes in the demographic structure of societies or the latest financial crisis not be traced back to individual decisions? Such constellations have in common that responsibility is attributable at different levels: attributed to regulation in the political sense, attributed to producers of products and services and their gain-interest, but also attributed to the appliers or consumers of such products. In the light of these constellations, the attribution of responsibility becomes precarious in the literal meaning of insecurity and revocability.

The idea to discuss such new forms of the attribution of responsibility in an interdisciplinary context arose from a striking observation: both in the research of the public sector from a political- and management-perspective and social scientific research, especially of science and technology studies, comparable difficulties and constellations regarding responsibility are observable. The main objective of this project is to bring the insights of such different fields together and to refer both perspectives to the hypothesis that the at- 
tribution of responsibility in modern society is the basis for fundamentally new mechanisms. The discussion of these inter-disciplinary similarities and differences in empirically diverse research contexts promises insights into the characteristics and consequences of a potentially more general development that will be of interest for a range of social sciences.

In his study on Trust (»Vertrauen«, first published 1968) Niklas Luhmann defends the hypothesis that a social change from personal trust to trust in systems had taken place. Trust in individual people was replaced by a generalized trust in the functioning of symbolically generalized media of communication (Luhmann 2000). For Luhmann, this study is the starting point for research in the recursive closing of communicative logics such as those of law, economics and science as the specificity of modern society. At the same time, individual people are marginalized and with regard to questions on the theory of society tackled only in the context of intimate relationships.

The self-dynamics of modern society are thus treated under the label of trust. With such a focus, Luhmann is far from alone. Not only in science- and technology studies, but generally in the research on risk, developing new technologies and social techniques are treated with regard of trust (Porter 1995; Goldman 2001). In other research areas exploring the development of new types of social structures, the focus is on trust, gaining, and retaining of trust (Gambetta 1988; Power 1997; Beckert 2005).

The starting point of this interdisciplinary research project is an enlargement of this focus on trust by taking the attribution of responsibility into account. Trust and responsibility lie close to each other. Trust works with reference to the future: since the current future necessarily is insecure in the present, trust is indispensible - trust in the functioning of techniques, trust in the stability of money or trust in the expertise of institutions or people. Responsibility, on the other hand, works with reference to the past: After something went wrong, mechanisms are necessary to deal with this fact and its consequences. Not only does this imply the relatively simple question of who is to overtake eventual material costs, but it also implies the more fundamental question of whether trust is retrospectively justified or is itself treated as irresponsible »blind trust «. Future-oriented trust and past-oriented attribution of responsibility are also closely related: it is easier to trust in the present if, when expectations were unfulfilled or when something went wrong, reliable mechanisms of responsibility-attribution are at hand. If such reliable mechanisms of the attribution of responsibility are lacking, it is most likely that this has consequences for the kind and nature of present trust.

Thus, expecting a relationship between trust and responsibility, the hypothesis is close, that a change from trust in people to trust in systems implies changes in the way in which responsibility is attributed. Of course, expectations are still pointed to social addresses, payments are attributed to people, and citizens are themselves responsible for their actions. Nevertheless, we can risk the hy- 
pothesis, that under condition of trust in systems, the way in which responsibility is attributed changes its social function. What new mechanisms and ways of the attribution of responsibility evolve when a default in knowledge, systems or things cannot unequivocally be attributed to the mistake of an individual person? What significance do people have if they are no longer the undisputed addresses of trust? And how does politics deal with the challenge of being held increasingly responsible for failed expectations?

This type of question is not sufficiently tackled by the research in trust and the development of new mechanisms of trust-building. Modern society is characterized by a number of mechanisms that might have a trust-building effect, but which are not covered by corresponding mechanisms of the attribution of responsibility in the case of disrupted expectations. For example, Michel Power observes its trust-building power as a main effect of the expanding auditingpractices (Power 1997). But if such trust is disappointed - as we can disagree with Power - the institutions occupied by auditing cannot be held responsible. A similar constellation is true for certificates of financial services or ecological products: they may foster trust, but if this trust is broken, the »responsibility « to have trusted at the wrong place is factually and in the media discourse even morally attributed to the consumer. Because the development of new mechanisms of trust building does not necessarily fall together with the development of new mechanisms of the attribution of responsibility in the case of broken trust, research into this past-oriented equivalent of the future-oriented trust is necessary.

In contrast to earlier research focuses, this project thus emphasizes the concept of responsibility instead of the concept of trust. It must be emphasized that the concept of responsibility is conceptualized here by the aspect of attribution, which is not necessarily an individual attribution. In contrast to philosophical perspectives of responsibility (such as Jonas 1984), the discussion here is not interested in the development of an ethical imperative, but in the societytheoretical, presence-diagnostic and historical investigation of a general development of society.

\section{Disciplinary approaches}

The empirical starting point - the self-dynamics of knowledge, systems and things - is treated in different disciplines of the social sciences. Above all, this holds for the - in themselves interdisciplinary oriented - sciences and technology studies. In the 1960s, technology was discussed with regard to a »power of facts «, under which politics should subordinate or not subordinate itself (Schelsky 1961; Habermas 1968). The discovery of ecological dangers, unintended side effects and strong path-dependencies since the 1970s was later observed under the label of the risk society (Beck 1986) and fostered the birth 
of science and technology studies for research in specificities, genesis and consequences of technical development (Rammert 1993; Petermann / Coenen 1999; Degele 2002). A new and critical viewpoint on science and technology is further developed by the research in the social conditions of the production of scientific truth: such scientific truths no longer appear as something that is »revealed « by research, but which is at least influenced by a specific social practice, personal power and the respective social conditions (Latour 1987; Jasanoff 1990; Wynne 1996; Knorr Cetina 2002).

The expectation of risk in connection with technology give rise to a new interest in trust and responsibility. This is increasingly the case, since the development of inherently new technologies such as genome- and nano-technology must be dealt with in daily life while their implications are foreseeably unforeseeable (Lemke 2004; Verbeek 2005; 2011). Conditions, mechanisms and challenges of the attribution of responsibility regarding self-dynamic and future-oriented developments become a topic for political- and management research or law theory, and confront sociology with new conceptional challenges. The demands on politics change in line with the extent to which the potentially unexpected implications of new knowledge themselves become expectable. The state is not only expected to foster positive developments and prevent manifest dangers, but also to tackle risks before they can show any unintended effects (Bora 2002, 262; Schuppert/Voßkuhle 2008, 264). For a long time and to some extent also today, the switch from steering to governance and thus the participation of several actor groups in potentially risky decisions could be the answer to the responsibility-problem of the state (Benz/Lütz/Schimank et al. 2007). But research at the border of governanceresearch or governmentality-studies shows the limits of participation as well as further, more implicit mechanisms of state intervention: the idle motion of participation procedures (Bora 1999); the steering power of the state lying in the politically opened room for self-organization (Andersen/Sand 2011); and the playful intervention of the state at the border between power and free decision (Andersen 2009) wins territory in the face of precarious political responsibility. Subtle mechanisms such as the shifting of responsibility and political orders for self-responsibility and thus a "governance of the self« fall into this research area (Bröckling/Krasmann/Lemke 2000; Lemke 2004; 2007b; 2007a; Andersen 2010; Andersen / Knudsen 2011).

Governance and the participation of potentially involved groups of actors take into account that certain decisions have effects for others than those taking the decision. New developments in law-theory deal with the opposite problem: that certain developments can no longer be traced back to one responsible decision-taker. To this new situation, law starts to react with the development of new instruments, which are discussed in law-theory. Particularly in ecological law and technical law, variations of joint responsibility of predefined actor groups are discussed on the dogmatic level (Teubner 1994; 2007; 
Lepsius 2003; 2004; 2009). The European legislation on chemicals »REACH« (Scheringer/Böschen/Hungerbühler 2006) can be taken as a prominent example of this development.

Finally, sociology is touched at its theoretical core by the difficulties of attributing socially important phenomena to individual actors. The fundamental problem here is the tension between the premise that only social actors such as people or organizations shall be regarded as valid addresses of attribution and the effects that self-dynamics of knowledge, systems and things seem to provoke. A radical proposition in this situation is Latour's idea of a $» r e-$ symmetrisation «. According to this concept, apart from people, things shall be taken as actants of a network which produces and hinders certain developments (Latour 1997; 1999). This proposition is situated at the border of sociological theory but obviously hits a point as the wide spread of Latour's ActorNetwork-Theory shows (see Belliger/Krieger 2006). Particularly with regard to technology, Latour's considerations are taken as an incentive to further develop and broaden sociological theory (Rammert/Schulz-Schaeffer 2002). Those approaches of broadening sociological theory can also be seen in the context of the research in the »borders of the social. The idea here is that the notion of social actors as human individuals is a specificity of modern society and can neither be found in the medieval ages nor in a culturally different society (Lindemann 2002; 2009b; 2009a). If this is the case, we can further develop this idea and explore the extent to which the »borders of the social « are currently under a change, taking electronic agents, health-care-robots and interactive things into account. The importance of such developments goes far beyond the sociology of technology in a narrow sense.

\section{Interdisciplinary questions}

The key idea of this approach to the topic of responsibility is that it is useful to observe responsibility from the point of view of second order observation. Accordingly, responsibility is not used as a normative term but rather as the object of analytical observation. This implies the premise that responsibility is not relevant automatically. Second order observation results in different questions and different answers when made from different disciplinary standpoints. At the same time, different degrees of second order observation are taken in. While some articles take two steps back rather than one, which involves a higher degree of abstraction, some others remain rather close to a first-order observation, which involves a higher propensity to normative arguments. Despite the risk that such a variety involves, the benefit of taking this risk is to respond to the complexity that the topic of responsibility necessarily involves and which can be seen as a tribute to an interdisciplinary approach. This research project aims to profit from synergies between the insights of po- 
litical- and management studies, social theory, law, politics and public health. To this end, the contributions are arranged along guiding questions. In this way, what may be lost in disciplinary preciseness will be recompensed by the potentially surprising interdisciplinary insights.

The first object of discussion will be responsibility-attribution and its limits. As a rule, responsibility is attributed to human individuals. But seen from a society-theoretical point of view, the attribution of responsibility exclusively to human individuals is historically contingent and requires the development of rather demanding structures. Gesa Lindemann shows how human dignity, as a structural feature of functional differentiation, must develop as a modern requirement for the attribution of responsibility to individual people. Harald Mieg starts his argument where Lindemann ended. If responsibility is accepted as a valid principle of modern society, it is far less monolithic than it sometimes seems. Instead, retrospective, prospective and status responsibility can be distinguished as three forms of responsibility. This allows for an analysis of the idea that under increased social reflection, more responsibility is performed. After this focus on the micro sociological situation, Sascha Dickel broadens the angle to a semantic analysis of technocracy as a dystopian self-description of society. He argues that in the technocratic image of society, responsibility is suspended by technological rationality. At the same time, in utopian discourses, the individual is still regarded as the hero of the technological age. In the intersection of dystopian and utopian descriptions, the individual is confronted with a negation of responsibility on the one hand and excessive expectations of personal responsibility on the other.

A discussion of the precarious attribution of responsibility leads to the thesis that the attribution of responsibility under the condition of trust in systems involves the development of new addresses of attribution. The second guiding question thus concerns New Mechanisms and Ways of Responsibility-Attribution. In the search for such new ways, Cristina Besio argues that the attribution of responsibility to individual actors still remains a frequent occurrence, but it is confronted with specific problems. Besio shows how organizations in highly uncertain situations attribute moral responsibility by activiating powerful pictures such as the »scapegoat« or the »firm founder«. This allows them to portray themselves as moral actors and acquire the internal and external backing necessary to continue operating. After this organizational perspective, Malte Gruber makes observations from the point of view of law. He states that in the crisis of individualistic concepts of causal attribution and culpability, the law increasingly reacts with collectivization. Responsibility for technological risk therefore has to focus on objective mechanisms of attributing responsibility to a company, an enterprise or another association of human and non-human entities. From this point of view, it is possible to trace the drift of legal attribution of responsibility as it can be observed in information-technological contexts and, for example, will face further challenges in excesses of flash mobs or 
flash trading (high-frequency trading). The contribution of Bettina Schmidt focuses on responsibility in the health sector from a public health position. Her starting point is that the attribution of responsibility for his or her own health to the patient has a strong class bias and is overall unrealistic. From a power perspective, the discourse of self-responsibility for health can be observed as an instrument to shift costs and moral guilt to those who are least prepared to defend themselves. Schmidt thus argues that new ways of responsibility attribution must be enforced which are more on an institutional than an individual level.

If it is true that under conditions of trust in a system, the way in which responsibility is attributed changes, this must have consequences for the role of people and the state. The third guiding question thus concerns self-responsibility and how such self-responsibility can be produced. Erik Højbjerg addresses this question by analyzing the case of financial literacy. In the aftermath of the 2008 global financial crisis, increasing the financial literacy of ordinary citizen-consumers has taken a prominent position among regulators and financial institutions alike. Højbjerg observes a corporate spread of financial literacy educational initiatives and analyzes them as a particular form of power at-a-distance responsibilizing the consumer. Andreas Eis and Claire MoulinDoos observe the phenomenon of self-responsibility from the perspective of political education. Current developments of an enlargement and diffusion of responsibility challenges political education, which traditionally follows the ideal-picture of the independent citizen (der »mündige Bürger«). Eis and Moulin-Doos argue that not only do modern political relations of responsibility shift, but they also tend to dissolve. This process is characterized by a depolitisation of social steering, which results in a normative new tendency of a "post-political« political education.

Closely linked with the question of responsibility of the individual is the attribution of responsibility to the state. For example, the latest crisis shows that, in the case of disappointed expectations, the state is among those held responsible. To what extent does a precarious attribution of responsibility involve (new) challenges of governance? Two corresponding perspectives on the challenges of governance close the discussion - the perspective of a »power at play« and the perspective of an »illusion of regulation as foundation of regulation«. Niels Akerstrøm Andersen and Hanne Knudsen observe a mechanism of responsibility-attribution under the condition of trust in systems that consists of responsibility games as a method used to make citizens responsible. They argue that responsibility games used both by the welfare state and organizations have at least two effects: First, that citizens learn to reflect on and investigate their responsibilities, and second, that the development of a »performing audience « as a new hybrid in which the citizen is both an object of treatment and a performer. Alfons Bora offers a different perspective on the possibilities of the state to deal with responsibility under conditions of trust 
in systems. He asks whether the social form of responsibility can be replaced by other forms in new regulatory settings of the world society. The answer is based on the assumption that responsibility requires a certain quality of the social address. In new forms of regulation the question is whether these minimum requirements are still fulfilled. The thesis being advocated in this article claims that responsibility in all forms of regulation requires sense-operating addresses. Against this background the question finally arises of how regulation can work under conditions where it becomes increasingly difficult to identify such addresses. Finally, Anna Henkel takes a society-theoretical point of view. Her hypothesis is that the function of a responsibility attribution to individual people consists of the reduction of complex systems dynamics to concretely attributable actions. Attribution of responsibility to concrete addresses thus allows tackling an increase in overall societal complexity- even if a »personal responsibility« remains a mere fiction. Henkel develops her argument with regard to the evolution of society. She closes by questioning the extent to which the attribution of responsibility to individual people might be exhausted as a mechanism of complexity reduction and if functional equivalents are possibly able to replace it.

\section{References}

Andersen, N. Åkerstrøm (2009): Power at Play. The Relationships between Play, Work and Governance. New York: Palgrave Macmillan.

Andersen, N. Åkerstrøm (2010): Wer ist Yum-Yum? Ein Cartoon-Staat im werden. Pp. 245-279 in: S. Roth/L. Scheiber/R. Wetzel (eds.), Organisation multimedial. Zum polyphonen Programm der nächsten Organisation. Heidelberg: Carl-Auer Verlag.

Andersen, N. Åkerstrøm/Knudsen, H. (2011). Health Games: Towards a Playful Responsiblity.

Andersen, N. Åkerstrøm/Sand, I.-J. (2011): Hybrid Forms of Governance - Self-Suspension of Power. London: Palgrave Macmillan.

Apel, K.-O. (1988): Diskurs und Verantwortung. Das Problem des Übergangs zur postkonventionellen Moral. Frankfurt a. M.: Suhrkamp.

Bayertz, K. (1995): Eine kurze Geschichte der Herkunft der Verantwortung. Pp. 3-71 in: K. Bayertz (ed.), Verantwortung. Prinzip oder Problem? Darmstadt: Wissenschaftliche Buchgesellschaft.

Beck, U. (1986): Risikogesellschaft. Auf dem Weg in eine andere Moderne. Frankfurt a. M.: Suhrkamp.

Beckert, J. (2005): Trust and the Performative Construction of Markets. Köln: MPIfG Discussion Paper 05/8. http://www.mpifg.de/pu/mpifg_dp/dp05-8.pdf.

Belliger, A./Krieger, D. (eds.) (2006): ANThology. Ein einführendes Handbuch zur Akteur-Netzwerk-Theorie. Bielefeld: transcript.

Benz, A. / Lütz, S. / Schimank, U. et al. (2007): Handbuch Governance. Theoretische Grundlagen und empirische Anwendungsfelder. Wiesbaden: VS Verlag.

Bora, A. (1999): Differenzierung und Inklusion. Partizipative Öffentlichkeit im Rechtssystem moderner Gesellschaften. Baden-Baden: Nomos Verlagsgesellschaft.

Bora, A. (2002): Ökologie der Kontrolle. Technikregulierung unter der Bedingung von Nicht-Wissen. Pp. 254-273 in: C. Engel/J. Halfmann/M. Schulte (eds.), Wissen Nichtwissen - Unsicheres Wissen. Baden-Baden: Nomos Verlagsgesellschaft. 
Bröckling, U. / Krasmann, S. / Lemke, T. (2000): Gouvernementalität der Gegenwart. Studien zur Ökonomisierung des Sozialen. Frankfurt a. M.: Suhrkamp.

Degele, N. (2002): Einführung in die Techniksoziologie. München: Wilhelm Fink Verlag.

Gambetta, D. (1988): Trust. Making and Breaking Cooperative Relations. New York/ Oxford: Basil Blackwell.

Giddens, A. (1999): Der dritte Weg. Die Erneuerung der sozialen Demokratie. Frankfurt a.M.: Suhrkamp.

Goldman, A. (2001): Experts: Which Ones Should You Trust? Philosophy and Phenomenological Research 63, 1, 85-110.

Habermas, J. (1968): Technik und Wissenschaft als »Ideologie«. Frankfurt a. M.: Suhrkamp.

Heidbrink, L. (2006): Verantwortung in der Zivilgesellschaft: Zur Konjunktur eines widersprüchlichen Prinzips. Pp. 13-38 in: L. Heidbrink/A. Hirsch (eds.), Verantwortung in der Zivilgesellschaft. Zur Konjunktur eines widersprüchlichen Prinzips. Frankfurt a. M.: Campus.

Jasanoff, S. (1990): The Fifth Branch. Science Advisers as Policymakers. Cambridge, Massachusetts: Harvard University Press.

Jonas, H. (1984): Das Prinzip Verantwortung. Versuch einer Ethik für die technologische Zivilisation. Frankfurt a. M.: Suhrkamp.

Kaufmann, F.-X. (2006): »Verantwortung« im Sozialstaatsdiskurs. Pp. 39-60 in: L. Heidbrink / A. Hirsch (eds.), Verantwortung in der Zivilgesellschaft. Frankfurt a. M.: Campus.

Knorr Cetina, K. (2002): Die Fabrikation von Erkenntnis. Zur Anthropologie der Naturwissenschaft. Frankfurt a. M.: Suhrkamp.

Krohn, W./Weyer, J. (1989): Gesellschaft als Labor. Die Erzeugung sozialer Risiken durch experimentelle Forschung. Soziale Welt 40, 3, 349-373.

Latour, B. (1987): Science in Action. Milton Keynes: Open University Press.

Latour, B. (1997): Nous n'avons jamais été modernes. Essai d'anthropologie symétrique. Paris: La Découverte.

Latour, B. (1999): Politiques de la nature. Comment faire entrer les sciences en démocratie. Paris: La Découverte.

Lemke, T. (2004): Veranlagung und Verantwortung. Genetische Diagnostik zwischen Selbstbestimmung und Schicksal. Bielefeld: transcript.

Lemke, T. (2007a): Susceptible individuals and risky rights: Dimensions of genetic responsibility. Pp. 151-165 in: R.V. Burri/J. Dumit (eds.), Biomedicine as Culture. Instrumental Practices, Technoscientific Knowledge, and New Modes of Life. New York/London: Routledge.

Lemke, T. (2007b): Von der Pflicht zur Selbstverantwortung. Zur Karriere eines Begriffs. Pp. 22-27 in: C. Plath (ed.), Demokratie üben. Münster: Westfälischer Kunstverein.

Lepsius, O. (2003): Vom Abfall zum Produkt. Wie Gegenstandserweiterungen Regelungsprobleme im Umweltrecht verursachen. NVwZ (Neue Zeitschrift für Verwaltungsrecht) 10, 1182-1188.

Lepsius, O. (2004): Risikosteuerung durch Verwaltungsrecht: Ermöglichung oder Begrenzung von Innovationen? VDStRL (Veröffentlichungen der Vereinigung der Deutschen Staatsrechtslehrer) 63, 264-315.

Lepsius, O. (2009): The Problem of De-Individualisation in the Risk-Society. Pp. 36-52 in: G. Woodman/D. Klippel (eds.), Risk and the Law. London: Routledge-Cavendish.

Lindemann, G. (2002a) Die Grenzen des Sozialen. Zur sozio-technischen Konstruktion von Leben und Tod in der Intensivmedizin. München: Wilhelm Fink.

Lindemann, G. (2007): Medicine as practice and culture. The analysis of border regimes and the necessity of a hermeneutics of physical bodies. Pp. 47-58 in: R. V. Burri/ J. Dumit (eds.), Biomediine as Culture: Instrumental Practices, Technoscientific Knowledge, and New Modes of Life. New York/London: Routledge.

Lindemann, G. (2009a): Gesellschaftliche Grenzregime und soziale Differenzierung. Zeitschrift für Soziologie 38, 2, 94-112. 
Lindemann, G. (2009b): Das Soziale von seinen Grenzen her denken. Weilerswist: Velbrück Wissenschaft.

Luhmann, N. (2000): Vertrauen. Ein Mechanismus der Reduktion sozialer Komplexität. Stuttgart: Lucius \& Lucius.

Nullmeier, F. (2006): Paradoxien der Eigenverantwortung. Pp. 151-164 in: L. Heidbrink/ A. Hirsch (eds.), Verantwortung in der Zivilgesellschaft. Frankfurt a. M.: Campus.

Petermann, T./Coenen, R. (eds.) (1999): Technikfolgenabschätzung in Deutschland Bilanz und Perspektiven. Frankfurt a. M.: Campus.

Porter, T. (1995): Trust in Numbers. The Pursuit of Objectivity in Science and Public Life. Princeton: Princeton University Press.

Power, M. (1997): The Audit Society. Rituals of Verification. Oxford: Oxford University Press.

Rammert, W. (1993): Technik aus soziologischer Perspektive. Opladen: Westdeutscher Verlag.

Rammert, W./Schulz-Schaeffer, I. (eds.) (2002): Können Maschinen handeln? Soziologische Beiträge zum Verhältnis von Mensch und Technik. Frankfurt a. M.: Campus.

Schelsky, H. (1961): Der Mensch in der wissenschaftlichen Zivilisation. Opladen: Westdeutscher Verlag.

Scheringer, M. / Böschen, S. / Hungerbühler, K. (2006): Will We Know More or Less about Chemical Risks unter REACH? CHIMIA 60, 10, 699-706.

Schmidt, B. (2008): Eigenverantwortung haben immer die Anderen. Der Eigenverantwortungsdiskurs im Gesundheitswesen. Bern: Verlag Hans Huber.

Schuppert, G.F./Voßkuhle, A. (2008): Governance von und durch Wissen. Baden-Baden: Nomos.

Teubner, G. (1994): Die unsichtbare »Cupola«: Kausalitätskrise und kollektive Zurechnung. Pp. 91-143 in: W. Lübbe (ed.), Kausalität und Zurechnung: Über Verantwortung in komplexen kulturellen Prozessen. Berlin: De Gruyter.

Teubner, G. (2007): Elektronische Agenten und grosse Menschenaffen: Zur Ausweitung des Akteursstatus in Recht und Politik. Pp. 1-30 in: P. Becchi/C. B. Graber/M. Luminati (eds.), Interdisziplinäre Wege in der juristischen Grundlagenforschung. Zürich: Schulthess.

Verbeek, P.-P. (2005): What Things Do: Philosophical Reflections on Technology, Agency and Design. Penn State University Press.

Verbeek, P.-P. (2011): Moralizing Technology: Understanding and Designing the Morality of Things. Chicago: University of Chicago Press.

Wynne, B. (1996): May the Sheep Safely Graze? A Reflexive View of the Expert-Lay Knowledge Divide. Pp. 44-78 in: S. Lash/B. Szerszynski/B. Wynne (eds.), Risk, Environment and Modernity. London: Sage Publications.

Prof. Dr. Anna Henkel

Carl von Ossietzky Universität Oldenburg

Institut für Sozialwissenschaften

Postfach 2503, D-26111 Oldenburg

anna.henkel@uni-oldenburg.de

Prof. Niels Åkerstrøm Andersen

Department of Management, Politics and Philosophy

Copenhagen Business School (CBS)

Porcelænshaven 18A, DK-2000 Frederiksberg

na.mpp@cbs.dk 
Copyright of Soziale Systeme is the property of Lucius \& Lucius Verlagsgesellschaft mbH and its content may not be copied or emailed to multiple sites or posted to a listserv without the copyright holder's express written permission. However, users may print, download, or email articles for individual use. 